\title{
Physical and Mechanical Characterization of Sugarcane Bagasse Particleboards for Civil Construction
}

\author{
Rosane A. G. Battistelle ${ }^{* 1}$, Danielle M. Fujino ${ }^{2}$, Ana L. C. e Silva ${ }^{3}$, \\ Barbara S. Bezerra ${ }^{4}$, Ivaldo de D. Valarelli ${ }^{5}$ \\ ${ }^{1}$ Department of Civil and Environmental Engineering, Faculty of Engineering of Bauru, \\ Sao Paulo State University, Bauru, SP, Brazil \\ e-mail: rosane@ feb.unesp.br \\ ${ }^{2}$ Department of Architecture and Urban Planning, Sao Paulo State University, Bauru, SP, Brazil \\ e-mail: mika fujino@hotmail.com \\ ${ }^{3}$ Department of Architecture and Urban Planning, Sao Paulo State University, Bauru, SP, Brazil \\ e-mail: analuiza_ces@hotmail.com \\ ${ }^{4}$ Department of Civil and Environmental Engineering, Faculty of Engineering of Bauru, \\ Sao Paulo State University, Bauru, SP, Brazil \\ e-mail: barbarabezerra@feb.unesp.br \\ ${ }^{5}$ Department of Mechanical Engineering, Faculty of Engineering of Bauru, Sao Paulo State University, \\ Bauru, SP, Brazil \\ e-mail: ivaldo@ feb.unesp.br
}

Cite as: Battistelle, R. A. G., Fujino, D. M., e Silva, A. L. C., Bezerra, B. S., Valarelli, I. d. D., Physical and Mechanical Characterization of Sugarcane Bagasse Particleboards for Civil Construction, J. sustain. dev. energy water environ. syst., 4(4), pp 408-417, 2016, DOI: http://dx.doi.org/10.13044/j.sdewes.2016.04.0031

\begin{abstract}
In the worldwide market of particleboard production, the use of alternative raw materials is increasing, due to high demand and lack of traditional raw material, despite efforts of reforestation. In Brazil, the main agricultural commodity is sugarcane due to the copious production of sugar and ethanol. In the state of São Paulo alone approximately 140 million tons of sugarcane bagasse are produced every year, from which around $70 \%$ is burned for energy production, not adding value to the residue and generating pollution to the environment; and the other $30 \%$ is sold for composting. The objective of this work is to add value to the sugarcane bagasse by using it as a raw material for particleboard production to be employed as flooring in the area of civil construction. To achieve this, the present research characterized the physical and mechanical characteristics of the particleboards with the following alternative raw materials: sugarcane bagasse and leaves of bamboo. Particleboards were produced to reach high density $\left(0.8 \mathrm{~g} / \mathrm{cm}^{3}\right)$ using the resin (bi-component) polyurethane castor oil. Tests for abrasion, roughness and resistance to denting and wear (Janka hardness) verified that the addition of leaves of bamboo in the mixtures, contrary to what was expected, did not confer a greater degree of resistance to the particleboards. Lastly, the results showed that sugarcane bagasse is a viable raw material alternative for the production of particleboards, intended to be used as products and flooring.
\end{abstract}

\section{KEYWORDS}

Sugarcane bagasse, Solid waste, Recycling, Particleboard.

\section{INTRODUCTION}

In the industrial and academic environment many researchers seek to optimize the use of residues from industrial and agribusiness activities in order to add value and applicability to them. Works such as [1] try to find a solution for disposal of Vitroplast

\footnotetext{
* Corresponding author
} 
FR4, a residual material from waste printed circuit boards production, and [2] uses scrap tire rubber in place of SBS in modified asphalt as an environmentally suitable alternative for Brazil.

In the case of the wood industry, there is a need to replace the demand for native woods by residues [3]. Thus, the following researches can be cited: [4] produced particleboards with treated Pinus $s p$ residues bonded with castor oil resin in different percentages, where physical and mechanical properties superior to Brazilian standards were obtained; [5] used municipal tree pruning wastes in particleboard production with urea-formaldehyde adhesive, establishing a connection between particle size and mechanical properties; [6] developed homogeneous particleboards with residues of Pinus elliottii wood joined with castor oil adhesive to evaluate the effect of the combination of pressure and temperature in the quality of the final product; [7] developed a panel constructed with reforestation wood and particleboards of sugarcane bagasse bonded with castor oil adhesive, as an alternative for the conventional system of side closing of the working chute in cattle handling facilities; [8] used planer waste and chips of Bambusa balcooa and Bambusa vulgaris bonded with urea formaldehyde, and found that the particleboards made of chips showed better strength properties compared to planer waste; also the $B$. vulgaris, produced better and well-glued particleboards compared to B. balcooa because of its superior adherence.

Urea-Formaldehyde (UF) is the most commonly used adhesive in the wood industry due to its low production cost and ease of use under a diversity of curing conditions. However, UF poses side effects to human health, making it necessary to reduce the content of UF in particleboard production. [9] studied how the use of ammonium nitrate as a hardener can compensate for a reduction of 5\% in the UF content, and obtained physical and mechanical properties that meet the requirements for general standard and building materials.

[10] used macademia nut shell (residues) and castor oil as a replacement for conventional materials such as, wood fibers and UF in particleboard production. Compared with traditional materials, the introduced residual materials presented values of modulus of rupture and modulus of elasticity that were about 50\% lower, not conforming to the required standards. For this reason, when using residues in particleboard production, it is necessary to test for the appropriate composition in terms of percentage of residue to be employed and its influence on the physical and mechanical characteristics of the particleboard in order to achieve the standard requirements.

One question that must be asked is if the use of these residues in particleboard production is beneficial for the environment. In order to answer this question two studies demonstrated through a Life Cycle Assessment (LCA), following the guidelines of the ISO 14040 series of standards, the environmental impact of particleboards produced with residues: [11] analyzed several scenarios of particleboard production in furniture industries and compared two adhesives UF and Melamine Urea-Formaldehyde (MUF), and the substitution of wood for residues of wood, and concluded that the addition of residues can promote lower environmental impacts and also that the MUF has more impact on the environment than UF; [12] performed a LCA in particleboards manufactured in laboratory scale with the residues of sugarcane bagasse (Saccharum spp) and pine wood shavings (Pinus elliottii) bonded with UF, the results showed that the potential environmental impact is mainly due to transportation of raw materials and largely by formaldehyde emission in the production and final disposal. In this way those papers pointed out that the industry must find adhesives that are more environmentally friendly than UF and MUF. Similar results about the environmental impact of UF were found in [13]. 
The particleboards produced with sugarcane bagasse have been used in laboratory scale [14] and presented results in accordance with the Brazilian standards [15, 16].

The present work proposes to use sugarcane bagasse as material for the manufacturing of particleboards together with the stem of bamboo leaves from the species Dendrocalamus giganteus bonded with the adhesive castor oil, with the intention to use it in different products (floors, walls and accessories), thus preventing its disposal in nature in a negative way, and also to use a more environmental friendly adhesive.

\section{BACKGROUND}

At present the main crop that moves Brazilian economy is sugarcane; its uses ranging from production of edible sugar, to the production of alcohol and ethanol, discarding significant amounts of bagasse as waste. This Brazilian sector encompasses a large part of agriculture, industry, mobility (transport), services and supply of labor to society.

The seeds of sugarcane were first brought to Brazil in 1532 and the cultivation of the different species began in the Province of São Vicente (São Paulo State). However, it was in the Northeast region, especially in the states of Pernambuco and Bahia where the mills multiplied [17].

The Brazilian sugarcane plantation began to rise in the 1970's due to the oil crisis, which affected industrialized countries with the inflationary increase in fossil fuel prices, further impacting oil-importing countries, such as Brazil. As a result there was the need to obtain energy from alternative sources, giving rise to the Proálcool (National Alcohol Program), a program whose main objective was to replace petroleum-based fuels by fuels of vegetable origin, i.e., the alcohol produced by sugarcane, called ethanol [18]. Thus, ethanol was developed with the purpose of providing more fuel possibilities in Brazil. In addition, it gave rise to a new technology, parallel to biofuel, which highlighted the production system: grinding and electricity production in industry.

Brazil is considered the largest producer of sugarcane in the world, followed by India and China, and the first in the world in the production of ethanol. The country accounts for more than half of the sugar traded in the world and should increase its production by an average of 3.25\% until 2018/2019 [19].

The State of São Paulo is not only considered a technological hub, but also has the largest number of sugar mills in Brazil (Figure 1).

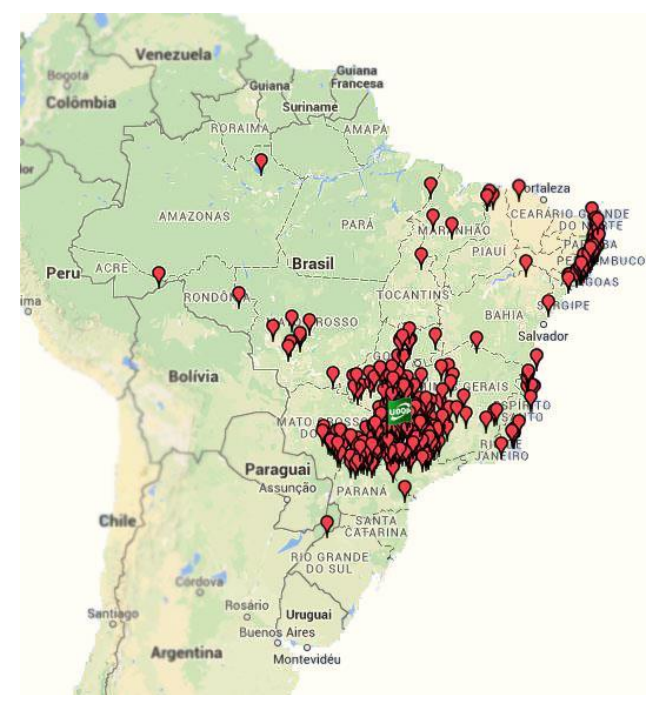

Figure 1. List of mills and distilleries in Brazil

(Source: Adapted from UDOP, http://www.udop.com.br) 
Despite the fact that the culture of sugarcane produces numerous benefits, mainly socioeconomic, a major problem relating to the production of sugarcane is the amount of waste it generates.

Among the wastes generated by the sugarcane industry is bagasse. Nowadays, several applications exist to minimize the negative impacts of bagasse as to its destination, such as burning it with an interest in generating energy to be used by the plants themselves (Figure 2), and using it as fuel, in which case it is responsible for the self-sufficiency of demands of thermal and electromechanical energies.

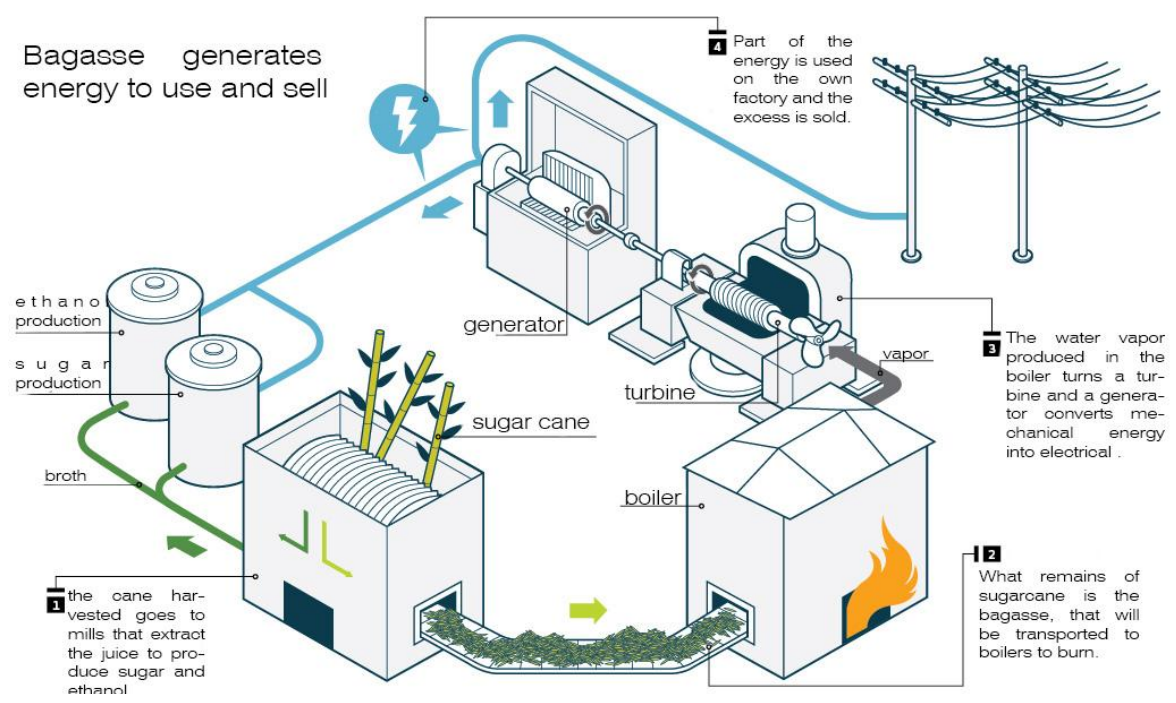

Figure 2. Process of burning sugarcane bagasse to produce energy (Source: Adapted from Revistagalileu.globo.com)

According to [20] the predominance of sugarcane based agriculture has the following negative impacts: biodiversity reduction caused by deforestation and deployment of sugarcane monoculture; contamination of surface water and soil through excessive use of fertilizers, mineral lime and application of herbicides (unregulated use of industrial by-products); soil compaction due to the traffic of heavy machinery during planting, cultural practices and harvesting; siltation of water bodies due to soil erosion in crop renewal areas; and production of soot and greenhouse gases from burning during the harvest period.

The Energy Situation Bulletin data held by [17] shows that the great growth of sugarcane harvest is followed by an increase in the generation of bagasse, according to the data presented in Table 1 .

Table 1. Offer of sugarcane bagasse

\begin{tabular}{lcccccc}
\hline \multirow{2}{*}{ Production (103 t) } & \multicolumn{3}{c}{$1^{\text {st }}$ quarter } & \multicolumn{3}{c}{12 months ending in March } \\
\cline { 2 - 7 } & 2013 & 2014 & $\Delta \%$ & 2013 & 2014 & $\Delta \%$ \\
\hline Sugarcane bagasse & $4,697.1$ & $6,585.9$ & 45.9 & $162,201.9$ & $180,713.8$ & 11.4 \\
\hline Source: Adapted from [19] & & & & & &
\end{tabular}

According to [21], there are several proven alternative uses for bagasse, such as animal feed, composition of structural plates, papermaking and hydrolysis to produce alcohol; its main use however, is to serve as fuel in boilers. It should be pointed out that even after meeting energy demands in the plant itself, some residue of bagasse can remain untapped, representing $8 \%$ to $15 \%$ of bagasse produced, according to [22]. 


\section{MATERIALS AND METHODS}

The materials employed in this research were the Sugarcane bagasse (SC), donated by Industry Tonon Bioenergia, located in Brotas City-SP - Brazil; Bamboo stem leaves (B), collected from the experimental field of UNESP in Bauru; and the polyurethane resin (polyol derived from castor oil and pre-polymer - isocyanate), made in Laboratory of Wood and Wooden Structures (Lamen-USP) in São Carlos - Brazil, as shown in Figures 3-5. The bamboo leaves are the residues from researches about bamboo used for structural purposes. Thus, due to the large amount of this waste generated in the laboratory there was a need to give it a proper disposal.

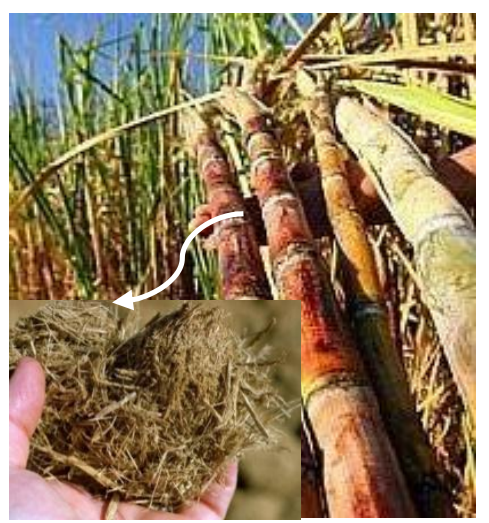

Figure 3. Sugarcane plantation in Brazil and its residue

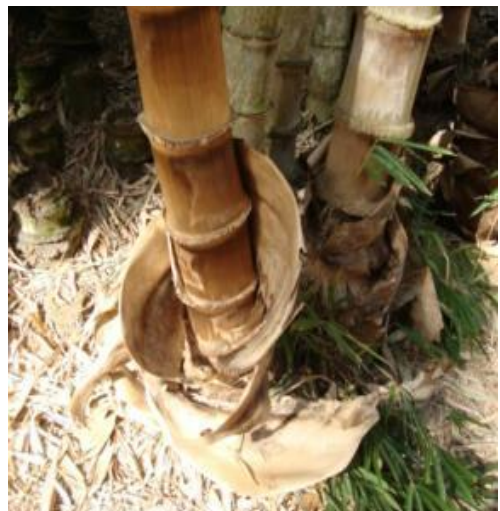

Figure 4. Sample of bamboo leaf used

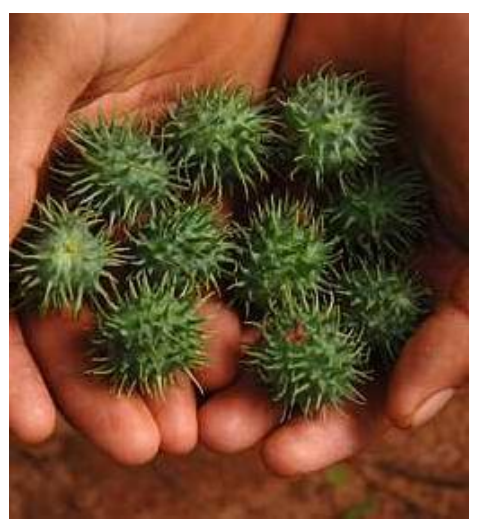

Figure 5. Plant from which polyol and isocyanate are extracted

After collecting the Bagasse (SC) it was sieved, the particle sizes used ranging from $1.2 \mathrm{~mm}$ to $4.0 \mathrm{~mm}$. After collection of Bamboo leaves (B) these were cut into smaller pieces and then crushed using an industrial crusher, Marconi model; and then they were sieved, obtaining particles with a size between $1.2 \mathrm{~mm}$ and $4.0 \mathrm{~mm}$. For each particleboard produced, a total of 1,706.88 $\mathrm{g}$ of residue (cane and bamboo) and $204.82 \mathrm{~g}$ of adhesive castor oil bicomponent (102.41 g polyol and $102.41 \mathrm{~g}$ prepolymer) were used. The established amount of adhesive was $12 \%$ in relation to the total mass.

The manufacturing process is summarized in Figure 6.

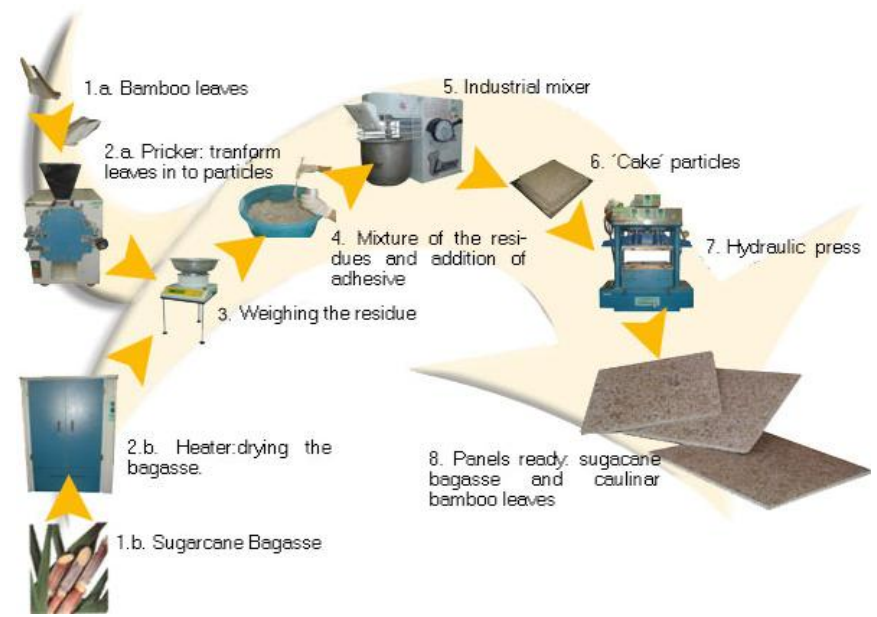

Figure 6. A summary of the manufacturing process in laboratory scale (Source: Adapted from: [12]) 
The particleboards (Figure 7) have pre-stipulated traces of $100 \% \mathrm{SC}, 75 \% \mathrm{SC}$, $+25 \% \mathrm{~B}, 50 \% \mathrm{SC}+50 \% \mathrm{~B}, 25 \% \mathrm{SC}+75 \% \mathrm{~B}, 100 \% \mathrm{~B}$ and were assessed for physical and mechanical performances through tests recommended by Brazilian standards $[15,16]$.

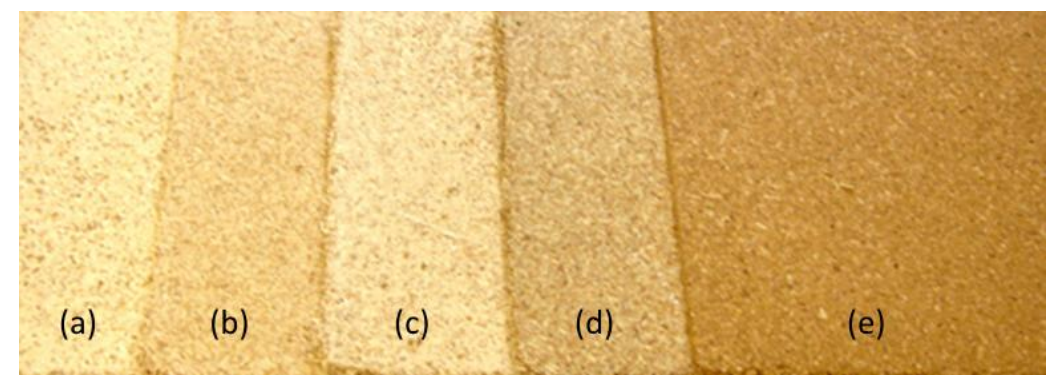

Figure 7. Samples of produced particleboards, with different traces: $100 \%$ SC (a); $75 \% \mathrm{SC}+25 \% \mathrm{~B}(\mathrm{~b}) ; 50 \% \mathrm{SC}+50 \% \mathrm{~B}(\mathrm{c}) ; 25 \%+75 \% \mathrm{~B}(\mathrm{~d}) ; 100 \% \mathrm{~B}(\mathrm{e})$

\section{RESULTS}

Tables 2 and 3 show a summary of the values obtained in the different physical and mechanical tests.

From the values presented in Tables 2 and 3, which contain all the results of physical and mechanical tests performed in this study, it was concluded that all traces obtained values within the recommended standards in Brazil and also when applicable, by international standards. The values found in this work were superior to our last research [22], where the sugarcane was employed for medium density particleboards.

Traces 1, 2 and 3 have excelled compared to traces 4 and 5. It can therefore be said that this is due to the greater amount of bamboo present in traces 4 and 5, which made pressing the particleboards difficult in the manufacturing process because the particles were relatively larger and more difficult to compress.

From the values presented in Tables 2 and 3, which contain all the results of physical and mechanical tests performed in this study, it was concluded that all traces obtained values within the recommended standards in Brazil and also when applicable, by international standards. The values found in this work were superior to our last research [22], where the sugarcane was employed for medium density particleboards.

Table 2. Results from physical tests

\begin{tabular}{|c|c|c|c|c|c|c|c|}
\hline & \multirow{3}{*}{ Trace } & \multicolumn{6}{|c|}{ Physical test } \\
\hline & & \multirow{2}{*}{$\begin{array}{l}\text { Density } \\
{\left[\mathrm{G} / \mathrm{cm}^{3}\right]} \\
(>0.8)^{*}\end{array}$} & \multirow{2}{*}{$\begin{array}{c}\text { Moisture } \\
\text { content [\%] } \\
(5-11)^{*}\end{array}$} & \multicolumn{2}{|c|}{ Water absorption [\%] } & \multicolumn{2}{|c|}{$\begin{array}{l}\text { Swelling [\%] } \\
(<8 \%-2 \mathrm{~h})^{*}\end{array}$} \\
\hline & & & & $2 \mathrm{~h}$ & $24 \mathrm{~h}$ & $2 \mathrm{~h}$ & $24 \mathrm{~h}$ \\
\hline 1 & $\begin{array}{c}100 \% \mathrm{SC} \\
0 \% \mathrm{~B}\end{array}$ & 0.87 & 7.65 & 9.85 & 31.65 & 2.01 & 10.8 \\
\hline 2 & $\begin{array}{c}75 \% \mathrm{SC} \\
25 \% \mathrm{~B}\end{array}$ & 0.85 & 7.78 & 8.21 & 29.73 & 1.8 & 10.78 \\
\hline 3 & $\begin{array}{c}50 \% \mathrm{SC} \\
50 \% \mathrm{~B}\end{array}$ & 0.87 & 7.17 & 8.17 & 30.75 & 2.34 & 11.32 \\
\hline 4 & $\begin{array}{c}25 \% \mathrm{SC} \\
75 \% \mathrm{~B}\end{array}$ & 0.83 & 7.46 & 8.17 & 30.75 & 2.46 & 10.24 \\
\hline 5 & $\begin{array}{c}0 \% \mathrm{SC} \\
100 \% \mathrm{~B}\end{array}$ & 0.82 & 7.62 & 10.1 & 37.27 & 2.93 & 12.81 \\
\hline
\end{tabular}


Table 3. Results from mechanical tests

\begin{tabular}{|c|c|c|c|c|c|c|c|c|c|}
\hline & \multirow{3}{*}{ Trace } & \multicolumn{8}{|c|}{ Mechanical tests } \\
\hline & & \multirow{2}{*}{$\begin{array}{l}\text { Parallel traction } \\
{\left[\mathrm{kgf} / \mathrm{cm}^{2}\right] \mathrm{F} 1} \\
(45-55 \mathrm{MPa})^{*}\end{array}$} & \multirow{2}{*}{$\begin{array}{c}\text { Perpendicular } \\
\text { traction }[\mathrm{MPa}] \\
(>0.4 \mathrm{MPa})^{*}\end{array}$} & \multicolumn{2}{|c|}{ Static bending [MPa] } & \multicolumn{2}{|c|}{ Screw pull $[\mathrm{N}]$} & \multicolumn{2}{|c|}{ Abrasion } \\
\hline & & & & $\begin{array}{c}\text { MOR } \\
(>18 \mathrm{MPa})^{*}\end{array}$ & $\begin{array}{c}\mathrm{MOE}^{* *} \\
(>2,450 \mathrm{MPa})\end{array}$ & $\begin{array}{c}\text { Top } \\
(>800 \mathrm{~N}) *(\end{array}$ & $\begin{array}{l}\text { Surface } \\
>1,020 \mathrm{~N})^{*}\end{array}$ & $\mathrm{M}[\%]$ & $\mathrm{E}[\%]$ \\
\hline 1 & $\begin{array}{c}100 \% \mathrm{SC} \\
0 \% \mathrm{~B}\end{array}$ & 204.61 & 1.15 & 37.05 & $6,470.78$ & $2,029.98$ & $2,005.5$ & 0.032 & 1.44 \\
\hline 2 & $\begin{array}{c}75 \% \text { SC } \\
25 \% \mathrm{~B}\end{array}$ & 176.09 & 1.11 & 34.49 & $6,864.7$ & $1,912.3$ & $1,652.4$ & 0.013 & 0.86 \\
\hline 3 & $\begin{array}{c}50 \% \mathrm{SC} \\
50 \% \mathrm{~B}\end{array}$ & 135.56 & 1.04 & 32.93 & $6,709.57$ & $2,093.72$ & $1,868.17$ & 0.028 & 0.75 \\
\hline 4 & $\begin{array}{c}25 \% \mathrm{SC} \\
75 \% \mathrm{~B}\end{array}$ & 118.66 & 0.92 & 28.62 & $5,767.61$ & $1,956.40$ & $1,721.07$ & 0.023 & 0.37 \\
\hline 5 & $\begin{array}{c}0 \% \mathrm{SC} \\
100 \% \mathrm{~B}\end{array}$ & 99.03 & 0.88 & 23.8 & $5,280.16$ & $1,824.04$ & $1,627.9$ & 0.094 & 0.54 \\
\hline
\end{tabular}

Traces 1, 2 and 3 have excelled compared to traces 4 and 5. It can therefore be said that this is due to the greater amount of bamboo present in traces 4 and 5, which made pressing the particleboards difficult in the manufacturing process because the particles were relatively larger and more difficult to compress.

Traces 2 and 3 stood out in relation to the values obtained in the physical tests because the panels had good compression ratio due to the presence of both the bamboo leaves and the bagasse.

In the thickness swell test, all traces obtained were within the requirements of ISO 14810-3, which establishes the maximum swelling parameter of $8 \%$ in 2 hours to plates with a thickness between 8 and $13 \mathrm{~cm}$.

The standard does not stipulate the maximum values for the absorption test; however, we sought a good indicator that absorbs the least amount of water, normally below $10 \%$. Some researchers working with resin derived from castor oil comment that the plates made with this resin have a microstructure with better accommodation of the particles with the resin, and so absorb the least amount of water.

Density is an extremely important factor in the results of the assays, since it depends on the compression ratio of the particleboards. In this work, plates with higher amounts of bamboo offered special resistance to compression due to the physiology of the matter. However, according to the obtained density $(d>0.8)$, all particleboards are within the high density feature.

For the perpendicular tension test, the standard establishes a minimum value of $0.40 \mathrm{MPa}$. Therefore, it can be seen that all plates obtained values well above the minimum required.

In the parallel traction resistance test, it can be seen that the highest value for the tensile strength, and hence the greater shear strength, lies in Trace 1, respectively with $1,318.04 \mathrm{kgf} / \mathrm{cm}^{3}$ and $204.61 \mathrm{kgf} / \mathrm{cm}^{3}$. These results are consistent when compared with [12], since their results also lead to a decrease in tensile strength and shear strength proportionately to the presence of bamboo, thus indicating a higher resistance of traces with higher concentration of sugarcane bagasse.

In relation to the bending test, the greatest value of Modulus of Rupture (MOR) is in Trace 1, with $37.05 \mathrm{MPa}$; and the lower, in Trace 5, with $23.8 \mathrm{MPa}$. In relation to the Modulus of Elasticity (MOE), the highest value obtained was in Trace 2, with 6,864.7 MPa; and the lowest value, in Trace 5, with 5,280.16 MPa. 
The NBR 14810-3 norm provides a minimum value of $800 \mathrm{~N}$ for screw pull at the top and $1,020 \mathrm{~N}$ at the surface, for panels from 14 to $20 \mathrm{~mm}$ thick; hence all studied panels lie within the stipulated value.

\section{FUTURE APPLICATIONS}

One of the goals of this research project is to try to expand the use of particleboards, not only in construction but also in the development of sustainable products related to Ecodesign, in the fields of Civil Engineering, Architecture, and Industrial Design. Examples of products developed with particleboards, stemming from industrial residues, are shown in Figures 8 and 9, and include a shelter for dogs and a foldable chair.

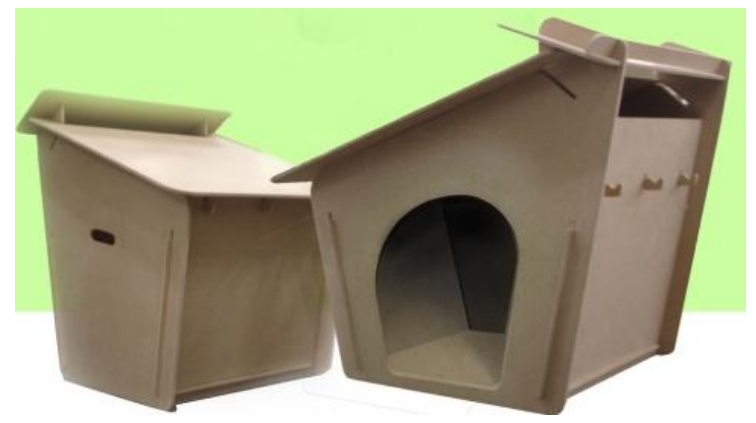

Figure 8. The manufacturing process of the dog house with different plates developed by the Ecoleo Design award-winning student Hugo Hissashi Hayashi

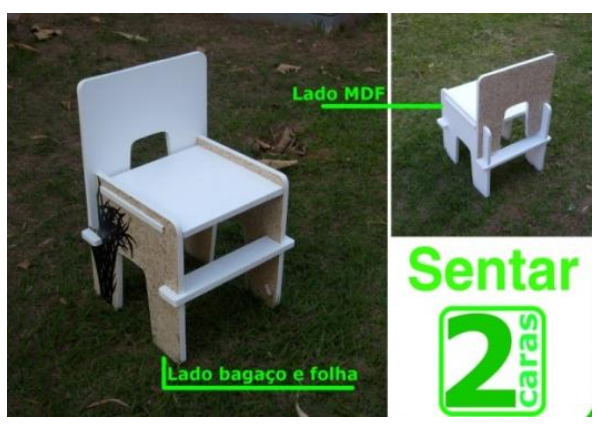

Figure 9. Foldable chair made of particleboards developed by the same student

\section{CONCLUSIONS}

The particleboards produced with sugarcane bagasse and Bamboo leaves proved to be technically feasible. From an environmental point of view the use of residues, although this study does not present a LCA analysis, can be environmentally advantageous. However, the LCA of the particleboards produced by $[12,13]$ indicate that the UF and MUF resins as the category with the highest impact index due to its toxicity both during the drying process of the particleboards, and in the final disposal. Although an LCA about the production, use and disposal of products made with castor oil adhesives was not found in the literature to date, the use of adhesive castor oil has the advantage of being a non-toxic product and can avoid the environmental impacts of the UF and MUF adhesives.

For future works it is recommended to conduct a LCA incorporating the adhesive castor oil, compared with the traditional particleboards produced with UF and MUF (traditional adhesives used in the wood industry).

In relation to furniture design, it can be said that the models described are apparently viable and meet the requirements of sustainable product because they use renewable and post-consumer recycled raw materials. A major limitation in the design of the project was the capacity of the hydraulic press used to produce each plate $(60 \mathrm{~cm} \times 60 \mathrm{~cm})$, which made it too complex to assemble furniture projects with large dimensions out of a single particleboard.

\section{ACKNOWLEDGEMENT}

The authors thank FAPESP (Fundação de Amparo à Pesquisa do Estado de São Paulo) for giving financial support to the research project 2014/08537-6. 


\section{REFERENCES}

1. Premur, V., Anić Vučinić, A., Vujević, D. and Bedeković, D., The Possibility for Environmental Friendly Recycling of Printed Circuit Boards, J. Sustain. Dev. Energy Water Environ. Syst., Vol. 4, No. 1, pp 14-22, 2016, http://dx.doi.org/10.13044/j.sdewes.2016.04.0002

2. Junior, A. F. A., Battistelle, R. A. G., Bezerra, B. S. and Castro, R., Use of Scrap Tire Rubber in Place of SBS in Modified Asphalt as an Environmentally Correct Alternative for Brazil, Journal of Cleaner production, Vol. 33, pp 236-238, 2012, http://dx.doi.org/10.1016/j.jclepro.2012.03.039

3. Saraiva-Cortez, A, M., Herva, M., García-Diéguez, C. and Roca, E., Assessing Environmental Sustainability of Particleboard Production Proccess by Ecological Footprint, Journal of Cleaner Production, Vol. 22, pp 301-308, 2013, http://dx.doi.org/10.1016/j.jclepro.2013.02.006

4. Bertolini, M. S., do Nascimento, M. F., Blecha, K. A. and Lahr, F. A. R., Eco-panels based on Wastes from Urban Trees and Castor Oil Polyurethane Resin, International Jounal of Agricultura and Forestry, Vol. 3, No. 1, pp 12-15, 2013, http://dx.doi.org/10.5923/j.ijaf.20130301.03

5. Silva, M. J. D., Bezerra, B. S., Battistelle, R. A. G. and Valarelli, I. D., Prospects for the use of Municipal Tree Pruning Wastes in Particleboard Production, Waste Management \& Research, Vol. 31, No. 9, pp 960-965, 2013, http://dx.doi.org/10.1177/0734242X13495101

6. Paes, J. B., Nunes, S. T., Lahr, F. A. R., Nascimento, M. De F. and Lacerda, R. M. De A., Quality of Particleboards of Pinus Elliottii bonded with Poliuretan Resin under different Combinations of Pressure and Temperature (in Portuguese), Ciência Florestal, Vol. 21, No. 3, pp 551-558.

7. Sartori, D., De, L., Cravo, J. C. M., Barrero, N. G., Fiorelli, J. and Junior. H. S., Panel in Wood of Reforestation and Particleboards for Agricultural Installations (in Portuguese), Floresta e Ambiente, pp 171-178, 2012.

8. Biswas, D., Bose, S. K. and Hossain, M. M., Physical and Mechanical Properties of Urea Formaldehyde-bonded Particleboard made from Bamboo Waste, International Journal of Adhesion \& Adhesives, Vol. 31, Issue 2, pp 84-87, 2011, http://dx.doi.org/10.1016/j.ijadhadh.2010.11.006

9. Aras, U., Kalaycioglu, H., Yel, H. and Bitek, G., Effects of Ammonium Nitrate on Physico-mechanical Properties and Formaldehyde Contents of Particleboard, Procedia - Social and Behavioral Sciences, Vol. 195, pp 2130-2134, 2015, http://dx.doi.org/10.1016/j.sbspro.2015.06.270

10. Wechsler, A., Zaharia, M., Crosky, A., Jones, H., Ramírez, M., Ballerini, A., Nuñez, M. and Sahajwalla, V., Macadamia (Macadamia integrifolia) Shell and Castor (Rícinios communis) Oil based Sustainable Particleboard: A Comparison of its Properties with Conventional Wood based Particleboard, Materials and Design, Vol. 50, pp 112-123, 2013.

11. Silva, D. A. L., Lahr, F. A. R., Varanda, L. D., Christoforo, A. L. and Ometto, A. R., Environmental Performance assessment of the Melamine-urea-formaldehyde (MUF) Resin Manufacture: A Case Study in Brazil, Journal of Cleaner Production, Vol. 96, pp 299-307, 2015, http://dx.doi.org/10.1016/j.jclepro.2014.03.007

12. dos Santos, M. F. N., Battistelle, R. A. G., Bezerra, B. S. and Varum, H. S. A., Comparative Study of the Life Cycle assessment of Particleboards made of Residues from Sugarcane Bagasse (Saccharum spp.) and Pine Wood Shavings (Pinus elliottii), Journal of Cleaner Production, Vol. 64, pp 345-355, 2013, http://dx.doi.org/10.1016/j.jclepro.2013.06.039 
13. Kouchaki-Penchah, H., Sharifi, M., Mousazadeh, H., Zarea-Hosseinabadi, H. and Nabavi-Pelesaraei, A., Gate to Gate Cycle assesment of Flat Pressed Particleboard Production in Islamic Republic of Iran, Journal of Cleaner Production, Vol. 112, Part 1, pp 343-350, 2016, http://dx.doi.org/10.1016/j.jclepro.2015.07.056

14. Battistelle, R. A. G., Proposed use of Bagasse from Sugar Cane into Particleboards for different Applications (in Portuguese), Full Professor Habilitation Thesis, UNESP, Brazil, 2011.

15. Brazilian Association of Technical Standards - ABNT, NBR 14810-3- Chipboard Sheets, Part 3: Test Methods, Rio de Janeiro, Brasil, 2002.

16. Brazilian Association of Technical Standards - ABNT, NBR 7190 Wooden Structures Project (in Portuguese), 1997.

17. Union Of Bioenergy-UDOP from Producers, Situation Bulletin Energetically, $1^{\text {st }}$ Quarter 2014 (in Portuguese).

18. Araújo, E. and Santos, J., Development of Cane Sugar of Culture in Brazil and its Relevance in the National Economy (in Portuguese), FACIDER - Scientific Journal, Place of Publication (edit the Translation Plugin ABNT Citation File), 2013.

19. Ministry of Agriculture: Cane Sugar-MAPA, Institutional Site, $<$ http://www.agricultura.gov.br/vegetal/culturas/cana-de-acucar> [Accessed: 08-July-2015]

20. Langowski, E., Quema of Cane a Practice used and abused (in Portuguese), 2007.

21. Leme, R. M., Estimation of Emissions of Air Pollutants and Water use in the Production of Electricity from Biomass Sugarcane/Rodrigo Marcelo Leme-Caminas, SP, 2005.

22. Macedo, I. C., Leal, M. R. L. V. and Silva, J. E. A. R., Assessment of Greenhouse Gas Emissions in the Production and use of Fuel Etanol in Brasil, Government of State of São Paulo, 2004.

23. American Society for Testing and Material ASTM - Standard Specification for Insulating Board (Cellulosic Fiber), Structural and Decorative, ASTM C 208-72, Annual Book of ASTM Standard, Part 18, pp 64-69, 1972. 